\title{
Canonical Discriminant Analysis for Hematological and Serum Biochemical Changes during Pregnancy Period in Squirrel Monkeys (Saimiri sciurea)
}

\author{
Takashi YOSHIDA, Masaaki HAMANO*, Keiko OHTOH*, \\ Fumiaki $\mathrm{COH}$, and Nobuo GOTO**
}

\author{
Tsukuba Primate Center for Medical Science, The National Institute of Health, Hachimandai, \\ Tsukuba-shi, Ibaraki 305, *The Corporation for Production and Research of \\ Laboratory Primates, Hachimandai, Tsukuba-shi, Ibaraki 305, and \\ ${ }^{* *}$ Laboratory of Animal Breeding, Faculty of Agriculture, Kobe \\ University, Nada-ku, Kobe-shi, Hyogo 657, Japan
}

(Received 27 November 1990/Accepted 23 January 1991)

\begin{abstract}
Hematological and serum biochemical data obtained from non-pregnant, pregnant and post-partum squirrel monkeys (Saimiri sciurea) were analyzed by canonical discriminant analysis (discriminant analysis with reduction of dimensionality). All animals were of wild origin and had been maintained under uniform environmental conditions at Tsukuba Primate Center for Medical Science, N. I. H., Japan. Months were standardized by the day of parturition. The calculated arithmetic means and standard deviations were listed for each item of measurement performed (Table 3, Figs. 1. 2. 3 and 4). Items detected statistically significant difference $(p<0.01)$ between months were as follows : red blood cell count $(\mathrm{RBC})$, mean corpuscular volume $(\mathrm{MCV})$, hematocrit value $(\mathrm{Ht})$, hemoglobin concentration $(\mathrm{Hb})$, white blood cell count (WBC), albumin concentration (ALB), blood urea nitrogen concentration (BUN), total cholesterol concentration ( $\mathrm{T}-\mathrm{CHO}$ ), triglyceride concentration (TG), alkaline phosphatase activity (ALP) and calcium concentration $(\mathrm{Ca})$. Results of canonical discriminant analysis showed that the value of the first canonical variate $\left(Z_{1}\right)$ decreased from the early period of pregnancy to the middle period, and that the second canonical variate $\left(Z_{2}\right)$ decreased from the middle period of pregnancy to the end of pregnancy. The meaning of their changes were discussed. - KEY WORDS : canonical discriminant analysis, hematology, pregnancy, serum biochemistry, squirrel monkey
\end{abstract}

リスザル (Saimiri sciurea) の血液学的ならびに 血清生化学的測定値の妊娠にともなら変化の

正準判別分析法による解析

\author{
吉田高志・浜野政章*·大藤圭子* \\ 長 文昭・後藤信男**
}

国立予防衛生研究所筑波医学実験用霊長類センター

*社団法人予防衛生協会

**神戸大学農学部家畜育種学教室 
リスザルは, 中・南米（新世界）を原産とし，広鼻猿 類に属する小型のサル類である。明確な季節繁殖特性を 示し, 原産地では 6 月から 9 月が交尾期であり12月から 翌年の 2 月にかけてが出産期である。しかし，北半球に 移して飼育した場合, 交尾期は 1 月から 3 月に，また出 産期は 5 月から 7 月へと, 約半年間のシフトを生じる が，明確な季節繁殖特性は維持し続ける $[22,23]$ 。

ところで, ヒトやラットの場合, 妊娠母体の血液は高 タンパク・高脂質状態を呈することはよく知られている [1,2,11] しかし，狭鼻猿類に属する旧世界ザルである カニクイザルの場合, Fujiwara ら [3] 拉よび我々の 研究 [20]によって, 妊娠母体の血液は, ヒトの場合と は異なり，低タンパク・低脂質状態を呈することが明ら かとなった。同様の報告はカニクイザルと同じマカカ属 のアカゲザル [8] やブタオザル [9] でなされている。 他方, 系統学的には, カニクイザルよりも, さらにヒト と離れている広鼻猿類のタマリン属のサルのほらが，妊 娠中に高脂質状態を呈し [13], 妊娠維持のための内分 泌動態あるいは妊娠中のコレステロールの代謝状態か ら，ヒトとの類似性が指摘されている $[2] 。$

しかし，タマリンに比較的近縁のリスザルでは血液学 的測定值の報告はあるものの [7]，奼娠および分婏を通 じての血液学的ならびに血清生化学的測定値（以下，血 液・血清生化学值) の変化についての研究は未だ無いよ らである。そこで，筑波医学実験用霊長類センターで飼 育されているリスザルを被験材料として，本研究を実施 した。

\section{材料および方法}

1. 動物㧍よび飼育・管理方式：ボリビア産, 野生由来 リスザル (Saimiri sciurea) の雌雄を用い, 長期同居 方式によって妊娠例を得た。動物の飼育管理方式の詳細 は既報 [4]のと扤りであり概略を記す。照明は14時間 明10時間暗とし, $100 \%$ 新鮮空気を 1 時間に 12 回換気し た。温度 $25 \pm 2{ }^{\circ} \mathrm{C}$, 湿度 $60 \pm 10 \%$ に設定した。飼料は 1 日 1 頭あたり午前中にリンゴ, ミカン各 $50 \mathrm{~g}$ ， バナナ 1/3本を, 午後に固形飼料50g（オリエンタル酵母社製, AS 型) および加熱ウズラ卵 1 個を与えた。ステンレス

Table 1. Number and body weight of animals examined

\begin{tabular}{ccc}
\hline Month* & Number & \multicolumn{2}{l}{$\begin{array}{l}\text { Mean body weight }(\mathrm{g}) \\
\text { with S.D. }\end{array}$} \\
-11 & 15 & $650 \pm 34$ \\
-9 & 11 & $624 \pm 45$ \\
-7 & 12 & $633 \pm 35$ \\
-5 & 6 & $665 \pm 43$ \\
-4 & 6 & $677 \pm 45$ \\
-3 & 6 & $693 \pm 46$ \\
-2 & 5 & $726 \pm 57$ \\
-1 & 6 & $798 \pm 64$ \\
0 & 4 & $838 \pm 31$ \\
+5 & 5 & $640 \pm 52$ \\
\hline
\end{tabular}

* Months were standardized by paturition.

Table 2. Analytical methods

\begin{tabular}{|c|c|c|c|}
\hline Item & (Abbreviation) & Method & Units \\
\hline Total protein concentration & $(\mathrm{TP})$ & Biuret reaction & $\mathrm{g} d \ell$ \\
\hline Albumin concentration & (ALB) & BCG method & $\mathrm{g} / \mathrm{d} \ell$ \\
\hline Albumin-globulin ratio & $\left(\begin{array}{ll}A & G\end{array}\right)$ & Calculated from TP and ALB & \\
\hline Blood urea nitrogen & $(\mathrm{BUN})$ & Urea-indophenol method & $\mathrm{mg} / \mathrm{d} \ell$ \\
\hline Glucose concentration & $(G L U)$ & Enzymatic method & $\mathrm{mg} \mathrm{d} \ell$ \\
\hline Total cholesterol concentration & $(\mathrm{T}-\mathrm{CHO})$ & Enzymatic method & $\mathrm{mg} / \mathrm{d} \ell$ \\
\hline Triglyceride concentration & $(\mathrm{TG})$ & Enzymatic method & $\mathrm{mg} \mathrm{d} \ell$ \\
\hline Alkaline phosphatase activity & $(\mathrm{ALP})$ & Kind-King's method & K. A. unit* \\
\hline Calcium concentration & (Ca) & $\mathrm{o}^{-}$Cresolphthalein complexone method & $\mathrm{mg} \mathrm{d} \ell$ \\
\hline Red blood cell count & $(\mathrm{RBC})$ & Microcell counter method & $\times 10^{4}$ cells $\mathrm{mm}^{3}$ \\
\hline Hematcrit value & $(\mathrm{Ht})$ & Microcell counter method & percent \\
\hline Mean corpuscular volume & $(\mathrm{MCV})$ & Microcell counter method & fl \\
\hline Hemoglobin concentration & (Hb) & Cyanomethemoglobin method & $\mathrm{g} d \ell$ \\
\hline White blood cell count & (WBC) & Microcell counter method & $\times 10^{3}$ cells $\mathrm{mm}^{3}$ \\
\hline
\end{tabular}

\footnotetext{
* King-Armstrong unit
} 
製金網ヶージ（W45×H60×D60cm）を 2 台もしくは 4 台連結し，雌雄の長期同居に用いた。触診により妊娠 が確認された個体は，直ちに個別飼育にした。被験材料 とした動物はすべて正常分婏したものである。分婏後 は，母仔を同居させ母ザルによる哺育をおこなったが， すべての母仔について分婏後 5 力月以内に母仔分離（離 乳）を怙こなった。その他の飼育・管理の詳細は既報の と怙りである $[5,6]$ 。対象とした動物数および採血時点 での体重を表に示した（ Table 1)。

2. 採血拈よび測定：採血は, 固形飼料の給䬣前の, 午 後 1 時から 2 時のあいだに, ケタミン塩酸（ケタラール 50 , 三共）による麻酔下 $(10 \mathrm{mg} / \mathrm{kg}$ 体重）で，大腿静

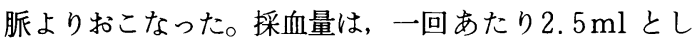
て，一部は採血後ただちに EDTAー2 Na を含む容器に 移し, 血夜学的検查に供した。残った血液は, 一晚 $4{ }^{\circ} \mathrm{C}$ に放置後， $4{ }^{\circ} \mathrm{C} 2,500 \mathrm{rpm} 15$ 分間の遠心分離によって血 清を得, 血清生化学検査に供した。測定項目, その略称 および測定方法を Table 2 に示した（以下，表中に示 した略号を用いる)。測定には血球自動計数装置および 血清自動分析装置を使用した。採血および測定の詳細は 既報のと扣りである [17]。

3. 統計学的処理：動物は，分婏月（（力月）を基準と して, 分婏前の 8 群（一11 -1 力月）および分婏後 5 カ月（+5 カ月）の計10群とした。分婏月の動物は，す べて分婏前に採血および測定をおこなったものである。 各群で項目ごとに平均值とその標準偏差 (S. D.) を求 めるとともに, 項目ごとに一元配置分散分析（F 検定） を施した。さらに同一測定值に多变量解析法を適用した [12]。解析方法としては, 相関行列に基づく正準判別分 析法を採用し, 計算には, パーソナルコンピューター （NEC，PC 9801）を，プログラムとしては田中らのも のを用いた [14]。

\section{成績}

1. 分婏月を基準とした測定值の変化 : 分婏月を基準と した各採血月ごとの血液・血清生化学值を Table 3 に 示した。14項目の測定で, 測定期間を通じて有意な変 動が認められなかった（ $\mathrm{p}>0.05 ）$ 項目は, TP, A/G, GLUであったが，他の11項目では，すべて高度に有意 $(\mathrm{p}<0.01)$ な変動が検出された。項目ごとの変動を図に 示す (Figs. 1, 2, 3 and 4)。娃娠中に批ける測定值の変 化は，概衫 4 つに類型化することがきた。その第 1 は， 妊娠とともに測定値の減少を示し, 分婏直前の時期にも っとも低值となり，分婏後もとの值まで回復するという

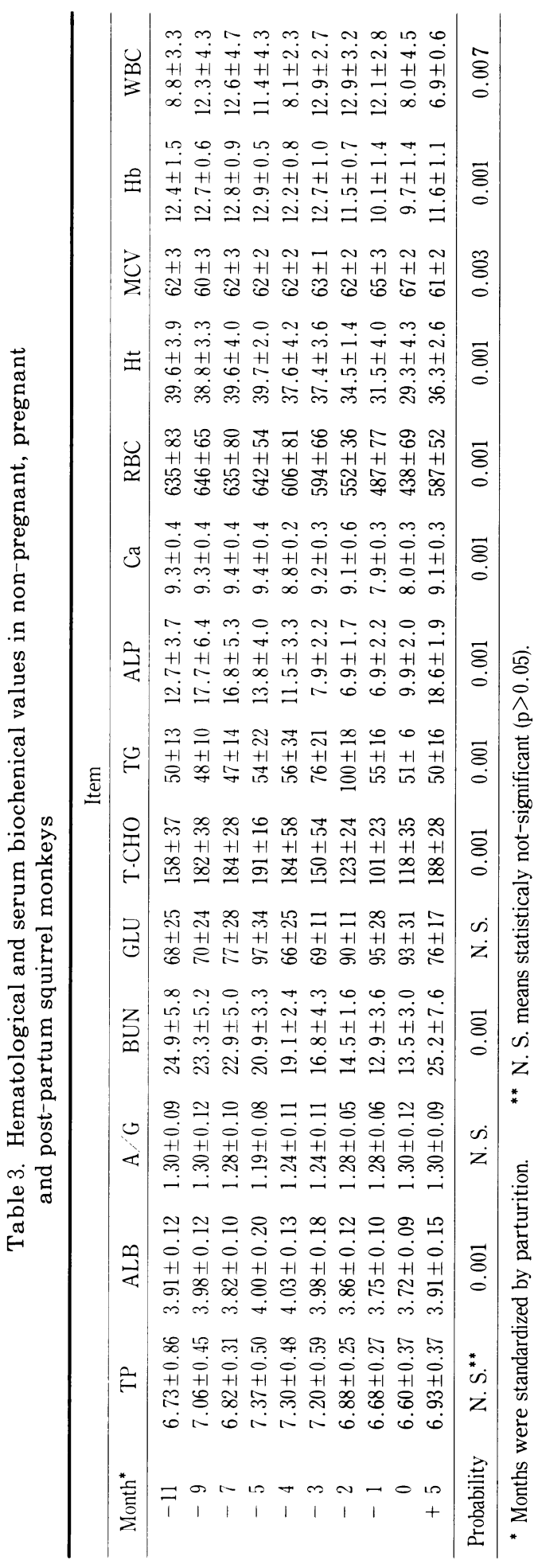




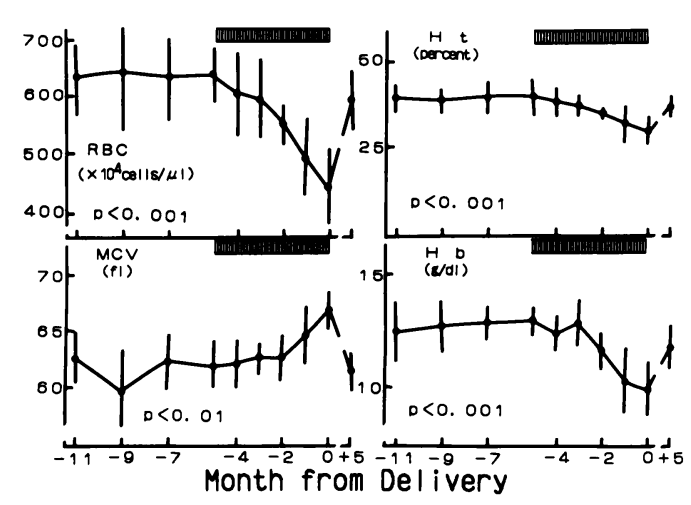

Fig. 1. Changes of red blood cell count (RBC, Mean \pm S. D.), mean corpuscular volume $(\mathrm{MCV})$, hematocrit value (Ht) and hemoglobin concentration $(\mathrm{Hb})$. Months were standardized by the day of paturition (0). Estimated period of pregnancy in the squirrel monkey ( between months were indicated in each figure.

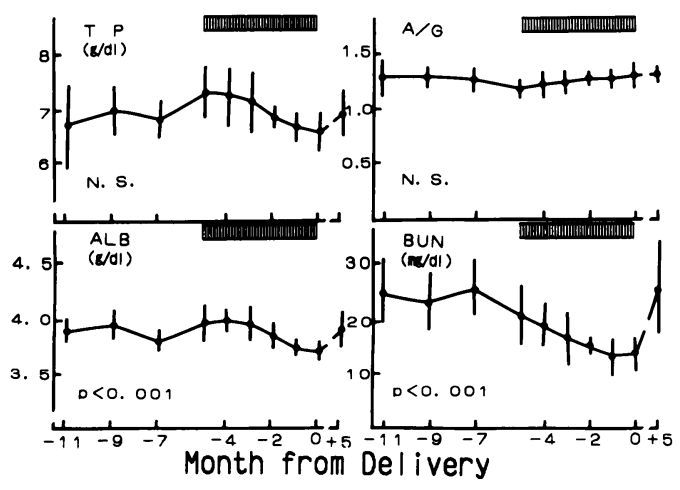

Fig. 2. Changes of total protein concentration (TP), albumin concentration (ALB), albuminglobulin ratio $(\mathrm{A} / \mathrm{C})$ and blood urea nitorogen (BUN). Data were arranged as described in Fig. 1.

もので, 項目としては RBC, Ht, Hb, BUN, T-CHO, Ca および ALPをあげることができる。第 2 のものは, MCV で, 第 1 のパターンとは逆の変動を示した。そし て第 3 のすのは, ALBで, 分婏前 5 力月目ごろから 3 カ月ごろまでは高値を，そして分婏前 2 力月目ごろから 分婏月までは低値を示したのち, 分婏後 5 力月目にはも との值に回復する，というあのである。TPについても，

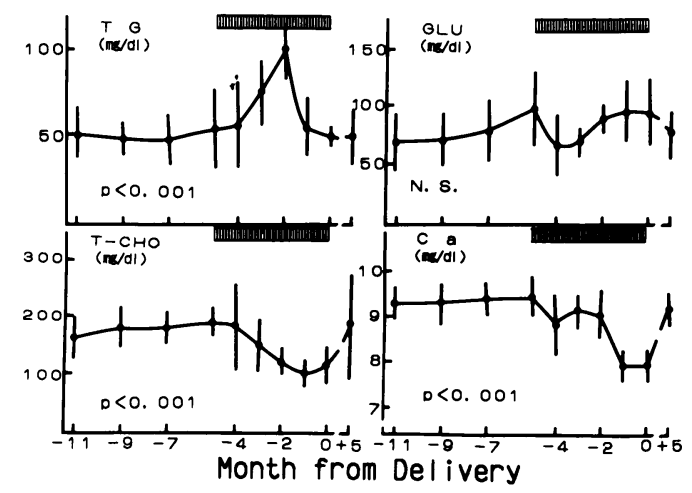

Fig. 3. Changes of triglyceride concentration (TG), total cholesterol concentration ( $\mathrm{T}$ $\mathrm{CHO}$ ), glucose concentration (GLU) and calcium concentration $(\mathrm{Ca})$. Data were arranged as described in Fig. 1.

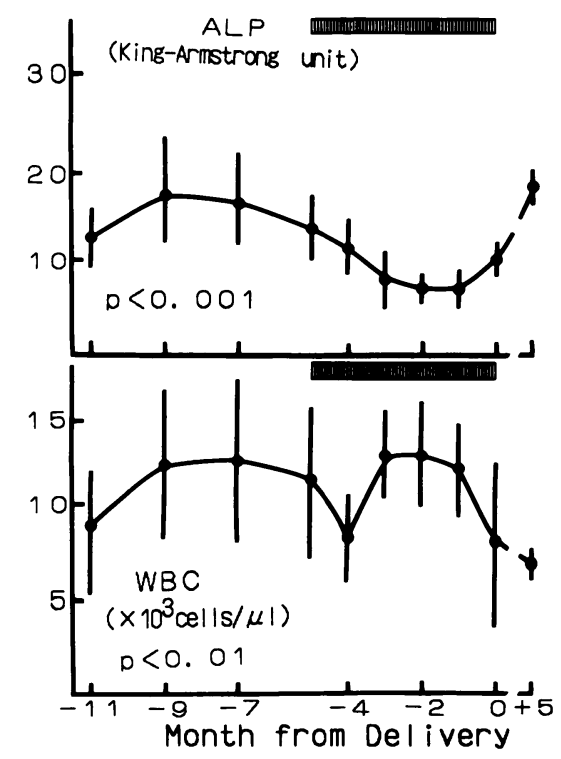

Fig. 4. Changes of alkaline phosphatase activity (ALP) and white blood cell count (RBC). Data were arranged as described in Fig. 1.

統計学的には有意性は検出されなかったもののALBの 変化とまったく同じ傾向を示した。そして，第4のもの はTG である。非妊娠時および妊娠末期にはほぼ同じ 值を呈しているものの, 妊娠の中期, すなわち分婏前 3 〜2 カ月目ごろのみに顕著に高い値を呈した。 
Table 4. Eigen vectors of the first $\left(Z_{1}\right)$ and second $\left(Z_{2}\right)$ canonical variates and contribution ratios of each variate

\begin{tabular}{lrr}
\hline & \multicolumn{1}{c}{$Z_{1}$} & \multicolumn{1}{c}{$Z_{2}$} \\
\hline TP & -0.5469 & 0.1570 \\
ALB & -1.2728 & 2.0804 \\
$\mathrm{~A} / \mathrm{G}$ & 0.8643 & 1.3703 \\
$\mathrm{BUN}$ & 0.1641 & -0.0240 \\
$\mathrm{GLU}$ & -0.0016 & -0.0051 \\
$\mathrm{~T}-\mathrm{CHO}$ & -0.0021 & 0.0019 \\
$\mathrm{TG}$ & -0.0276 & 0.0439 \\
$\mathrm{ALP}$ & 0.1805 & -0.1327 \\
$\mathrm{Ca}$ & 1.1120 & 1.2679 \\
$\mathrm{RBC}$ & -0.0008 & -0.0666 \\
$\mathrm{Ht}$ & 0.1229 & 1.1642 \\
$\mathrm{MCV}$ & -0.1368 & -0.7371 \\
$\mathrm{Hb}$ & 0.3860 & -0.3402 \\
WBC & -0.0272 & 0.0248 \\
\hline Contribution ratio & $67.41 \%$ & $14.04 \%$ \\
Cumulative & & \\
contribution ratio & - & $81.45 \%$ \\
\hline
\end{tabular}

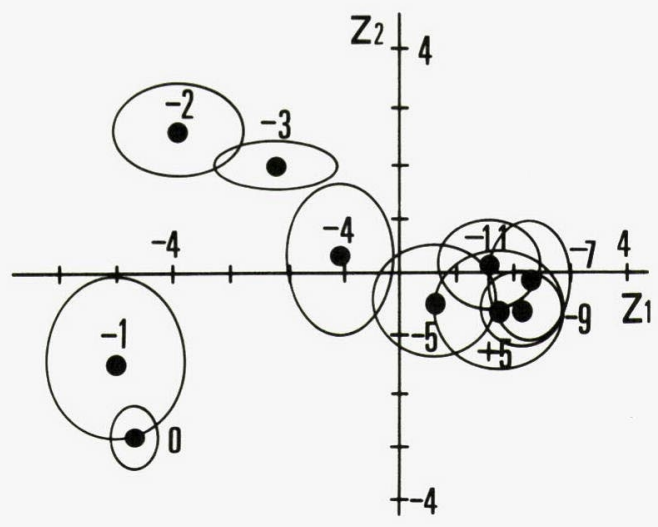

Fig. 5. Scattering diagram with $68.3 \%$ probability ellipse of each group on two-dimentional plane, $Z_{1}-Z_{2}$, as determined by canonical discriminant analysis. Cumulative contribution ratio of the $Z_{1}$ and $Z_{2}$ was $81.5 \%$.

2. 正準判別分析法の適用結果：14測定項目（変量）間 の91の組合せのうちで44の組合せ (48\%) で瓦に有意な $(\mathrm{p}<0.05)$ 相関性が認められ, そのうち 29 の組合世 (32\%) で高度な $(\mathrm{p}<0.01)$ 相関性が認められた。そ れらのなかには, TP と高度に (ALB, A/G, T-CHO，
$\mathrm{Ht}, \mathrm{Hb})$, また有意に $(\mathrm{Ca}, \mathrm{RBC})$ 相関した組合せや, $\mathrm{A} / \mathrm{G}$ 之高度に (TP, ALB, GLU, T-C HO, Ht, Hb), また有意に $(\mathrm{RBC})$ 相関した組合せが含まれていた。そ して, 正準判別分析の結果, 第 1 正準変量 $\left(Z_{1}\right)$ の寄与 率は67.4\%, 第 2 正準変量 $\left(Z_{2}\right)$ のそれを加えた累積 寄与率は， $81.5 \%$ であった (Table 4)。 $Z_{1}$ に係わる固 有べクトルの係数の絶対值が大きく判別への寄与の大き な項目は, TP, ALB, A/G, Ca, Hb 等であり, $Z_{2}$ に係 わるとれは, ALB, A/G, Ca, Ht, MCV 等であった。 $Z_{1}-Z_{2}$ 平面上で採血月ごとの各群の位置を図に示した (Fig. 5)。分婏前11 力月目から 5 力月目までの各群は, $Z_{1}$ の值が正で $Z_{2}$ の值がゼロに近く, 戝の右方に位置を 占めた。しかし, 分婏前 4 力月目から 2 力月目までは, 図中左上方に移動した。すなわちZ ${ }_{1}$ の值は負になると ともに, $Z_{2}$ の值は正に变化した。さらに, 分婏前 2 力 月目から分婏月にかけて, $Z_{1}$ の值には大きな変化は認 められないものの, $\mathrm{Z}_{2}$ の值は正から負へと大きく変化 した。一方, 分婏後 5 力月目の群は, 戝の右方に位置 し, 分婏前 $11 \sim 5$ 力月目の群と区別がつかなかった。

\section{考察}

旧世界ザルのオナガザル科マカク属のカニクイザルな どでは, 性周期を規則的な性器出血（月経出血）の観察 により容易に把握することができる。そのため, 排卵時 期に雌雄を同居させ妊娠例を作出する適期交配 (Timed mating) が可能である $[5,6]$ 。しかし，新世界ザルで あるマーモセット科のタマリンやオマキザル科のリスザ ルなどでは, 交配適期の推定を外観的指標によって簡便 に捛こならことは困難である。今回の妊娠例は雌雄の長 期同居方式によって得た。したがって妊娠齢を正確に知 ることが困難である。そこで, 本研究では, 分婏月(日) を基準として逆算した月秢を指標として用いた。分婏月 の採血は，すべて分婏前に統一した。リスザルの妊娠期 間は，5 カ月くらいであろらと推定されている[10]。

$$
\text { ところで我々は, これまで血液を } 1 \text { 晚 } 4 \text { ' C に保存し, }
$$
翌日の午前中に血清分離を拈こない, 血清生化学値の測 定に供してきた $[15]$ 。血清分離の条件がこれら血清生 化学的測定値に影響を及ぼすことを充分考慮する必要が あり, 我々もいくつかの検討を加えた $[16]$ 。その結果, GLU に関しては, 解糖系酵素阻害作用を有する抗凝固 剂 $(\mathrm{NaF})$ 添加時よりる低值 (平均 $14 \mathrm{mg} / \mathrm{dl}$ 低下する) となるものの, 添加時との相関性は高度に有意であり $(r>0.9)$, 我々が执こなっている検体処理手順によっ て種々の測定をおこならことにより動物の生理状態の把 
握は充分に可能である，と判断した。

本研究で用いた, タマリンとも系統的に近縁であり同 じ新世界ザルであるリスザルでは，タマリンの場合と異 なり [2]，妊娠期間中，母体血清は，低 T-CHO 状態 をを呈し，むしろ妊娠カニクイザルの場合 [20］に類似 した成績が得られた。他方, TGは，妊娠の中期頃と推 定される分婏前 $3 \sim 2$ 力月目に, 一過性の高値を呈し, 明らかにカニクイザルと異なる結果であった。以上の成 績から, 妊娠母体の血液・血清生化学値の変化, すなわ ち，栄養学的あるいは物質代謝に拈ける母体と胎仔との 係り方は, 必らずしも系統学的類縁関係を反映するもの ではないことを指摘することができよう。

ところで, 妊娠中のリスザルの血液・血清生化学値の 変化について，さらに詳細かつ総合的に検討を加える目 的で, 多変量解析法を適用した。これは, 本研究に用い た14変量間の約半分 (48\%) の組合せで変量相互に, 統 計学的に有意な相関関係があり，その相関珄を考慮した いためである。方法としては，正準判別分析法（次元の 减少をともなら判別分析法）を採用した。サル類の血液 - 血清生化学值の解析のために, 正準判別分析法の適用 が有効であることを，我々はこれまでに指摘してきた [13，18-22]。本研究においても，14変量に含まれる情報 を，2つの合成変量 $\left(Z_{1}, Z_{2}\right)$ に要約したところ，81.5 $\%$ の情報を $Z_{1}-Z_{2}$ 平面上に示すことができた。すなわ ち，14変量を 2 つ合成変量に要約した結果による情報 量の損失は18.5\%にしかすぎなかった訳である。

$Z_{1}-Z_{2}$ 平面上の各群は, 分婏前 5 力月以前の群 (一 11〜ー5 ) は, 図の右のほとんど同じ場所に位置し, 相 互に判別することはできなかった。他方, 分婏前 5 力月 目 $(-5)$ から分婏前 2 力月目 $(-2)$ にかけて， $Z_{1}$ の 値は負になるとともに, $Z_{2}$ の值も除々に正の値を呈す るようになった。リスザルの推定妊娠期間は 5 力月ぐら

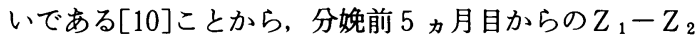
平面上での移動の開始は, 血液・血清生化学値にみられ る妊娠前期の変化を検出しているものと判断され，その 変化はおおむね $Z_{1}$ によって検出しているといえよう。 分婏前 2 力月目 $(-2)$ から分婏月（0）にかけては, $Z_{1}$ の値には大差がないものの, $Z_{2}$ の値は, 顕著に減少 した。 $Z_{2}{ }_{2}$ 軸によって, 血液・血清生化学値の妊娠後期 にみられる変化を検出しているものと判断される。すな わち，妊娠中期（分婏前 2 力月）をはさんで，妊娠りス ザルの血液・血清生化学值の変化の方向が明らかに異な っていることが示唆される。

$Z_{1}$ に係わる固有べクトルの係数の正で大きい值を呈 しているものは, A/G, Ca, Hbであり, 負で大さな值
を呈しているものは, TP, ALBであった。妊娠前期で は, $Z_{1}$ の值は負の方向に変化することから， A/G, Ca， $\mathrm{Hb}$ は相対的に低値を, TP, ALB は高値を呈している ことが期待される。改めて，それぞれの測定值を見る と, TP, ALBは, 妊娠前期には比較的高値を, そし て，妊娠後期には，低值を呈しており（Fig. 2)，また $\mathrm{Ca}$ b非妊娠時（分婏前 5 力月以前）に対して低值の傾 向を示した（Fig. 3)。

他方， $Z_{2}$ に係わる固有ベクトルの係数を見ると，正 で大きいものは, ALB, A/G, Ca, Ht であり，負で大 きいものは，MCVであった。妊娠後期に Z ${ }_{2}$ の值が顕 著に減少したことは，項目ごとに見てもそのころに $\mathrm{ALB}, \mathrm{Ca}, \mathrm{Ht}$ の測定值が減少し, MCV の測定值が高 值を示したことと対応した結果であると判断される。 妊娠前, 妊娠, 分婏と各時期で変動の小さかった $\mathrm{TP}$, $\mathrm{A} / \mathrm{G}$ が $Z_{1}, Z_{2}$ ともに, 各群の判別にかなり寄与して いた。 TP, A/G ともに, 項目ごとの検討では有意な変 動は検出されなかった。しかし，項目間での相関性を見 た場合, TP, A/G ともに, 項目ごとでの検討で有意な 変動を呈した多くの項目, たとえば ALB, T-C HO, $\mathrm{Ca}, \mathrm{R} \mathrm{BC}, \mathrm{Ht}, \mathrm{Hb}$ 等と有意な相関が認められた。この ことから有意にはならなかったとはいえ TP, A/G は, これら有意な変動を呈した項目と相関していることが推 測される。すなわち, 項目ごとの検討では有意性を認め ることができなかったものの, 判別へのこれらの項目の 寄与の大きさからみて, 統計学上の第 II 種の過誤（差が 無いといら㷌無仮説が誤っているにもかかわらず受け入 れてしまら場合）を生じたのかも知れない。さらに， $\mathrm{A} / \mathrm{G}$ は, TP と ALB の差をグロブリン量として算出 し，ALB との比をとったものである。このことは，A/ G は, TP および ALBに対し完全に独立したものでは 無いことを意味している。しかし，生理学的に見て A/ G は意義深い項目であることから, 検討の対象項目に 含めた。このような合成変量を, 多変量解析の対象項目 とした結果, 計算の過程で $\mathrm{A} / \mathrm{G}$ が過大に評価されてし まったのかも知れない。

とはいえ，項目ごとに見ても，TP，ALBが，妊娠前 期には高値傾向を，妊娠後期には低値の傾向を呈するこ と、扣よび $\mathrm{Ca}, \mathrm{Ht}$ が妊娠前期に低值を呈すること，さ らに MCV が妊娠後期に顕著に上昇すること, 等々の リスザルの妊娠前期と妊娠後期での血液・血清生化学值 の変化の違いを, $Z_{1}$ 扩よび $Z_{2}$ によって検出できたもの と思われる。すなわち, 妊娠中のリスザルの血液・血清 生化学值は, 分婏前 2 力月目 (一2) をはさんで妊娠前 期と妊娠後期とで変化のし方が異なる, と結論すること 
ができょう。そして, 分婏 5 力月後 $(+5)$ には, 明ら かに非妊娠時と同じ血液・血清生化学値を呈しているこ とは, 項目ごとの測定値を見ても， $Z_{1}-Z_{2}$ 平面上の位 置からも結論することができる。

ところで, 我々は多変量解析法の1つである正準判別 分析法を用いて, サル類の血液 - 血清生化学值の解析を おこなってきた $[13,18-22]$ 。これは, 互いに相関して 変化することの多い血液・血清生化学値を, 項目間の相 関性について考虑し，総合的に評価したいためである [12］。多变量解析法のうち比較的知られている主成分分 析法も適用したが，この方法では，情報の集約（寄与 率）があまり大きくなく，結果として正準判別分析法を 適用することになった。そして，カニクイザルの場合， 血液 · 血清生化学値は, 妊娠のはじめの $1 / 4$ の時期に, それまでの非妊娠型にちかいものから，妊娠型に大きく 変化すると報告した $[20]$ 。他方, タマリンの場合は, 妊娠中期に，それまでの非妊娠型にちかいるのから，妊 娠型に大きく変化すると述べた [13]。しかし，リスザ ルの場合は本研究で述べるように，妊娠初期から徐々に 変化が始まるとともに, 妊娠中期を境として, さらに大 きく変化するという型を呈していることになる。これら 三種の動物で見られた血液・血清生化学値の妊娠中の変 化の型の違いは, 項目ごとの検討によってのみでは, 必 らずしも明確にし得ない。血液・血清生化学值に対し多 変量解析法を適用し総合的に評価を加えることによって はじめて可能となったものと判断される。このような総 合的に見た妊娠中の血液・血清生化学値のサル種による 変化の型のちがいの生物学的意味については, 現在のと ころ不明である。今後, 調査の対象とするサル種を増や すことにより, 系統発生学的な検討等をおこなら必要が ある。他方, 正準判別分析法による $Z_{1}$ および $Z_{2}$ の得点 は, 個体毎での各変量の重み付け平均值とみなすことが できる。このことから，それぞれの測定值からは，妊 娠, 非妊娠あるいは妊娠の時期等の推測が的確にできな くとも，それぞれの個体についてすべての測定值と固有 ベクトルのそれぞれの係数を用いて $Z_{1}$ および $Z_{2}$ の得点 を算出することにより，すべての情報によって動物の状 態を推定する，といら利用法も可能である。今後このよ らな計量診断学的利用についても発展させてゆく必要が ある。

先きに項目ごとでの検討で，妊娠母体の血液・血清生 化学值の変化を, 栄着学的あるいは物質代謝における母 体と胎仔との係り方として考察を加えた。多変量解析法 の適用によって検出された妊娠中の母体の血液・血清生 化学值における変化の型の違いは，3種のサル種におけ
る母体と胎仔との係わり方の違いを反映しているものと 思われる。そして，同じ新世界ザルであるタマリンとリ スザルにおいてさえ，その係わり方に違いがあるのかも 知れない。今後, 他のサル種を含めた詳細な研究が要望 される。

\section{要 約}

筑波医学実験用霊長類センターの繁殖コロニーで, 雌 雄の長期同居方式によって妊娠したリスザルの血夜学的. 血清生化学的測定値（14変量）について解析を加えた。 項目ごとの検討で調査期間中, 有意な変動 $(\mathrm{p}<0.01)$ が検出された項目は, 血液学的検査では, 赤血球数, 平 均赤血球容積, ヘマトクリット值, へモグロビン濃度, 白血球数であり, 血清生化学検査では, アルブミン量, 尿素窒素量, 総コレステロール量, 中性脂肪量, アルカ リ性フォスファターゼ活性およびカルシウム量であっ た。これらの測定值に多変量解析法のひとつである正準 判別分析法を適用したところ，リスザルの妊娠にともな 5血液・血清性状の総合的な変化のうち前期の変化を第 1 正準変量の変化として, 後期の変化を第 2 正準変量の 変化として検出することができた。

\section{文献}

[1] Allen, J. R. and Ahlgren, S. A. (1968). A comparative study of the hematologic change in pregnancy in the Macaca mulatta monkey and the human female. Am J. Obst. \& Gynec., 100, 894-903.

[2] Feingold, K. R., Wiley, T., Moser, A. H., Lear, S. R., and Wiley, M. H. (1983). De novo cholesterogenesis in pregnancy, J. Lab. Clin Med, 101, 256-263.

[3] Fujiwara, T., Suzaki, Y., Yoshioka, Y., and Honjo, S. (1974). Hematological changes during pregnancy and postpartum period in cynomolgus monkeys (Macaca fascicularis). Exp. Anim 23, 137-146.

［4］浜野政章・吉田高志・長 文昭・後藤信男 (1990)。乳 仔期リスザルの体重成長とその管理の方法. 実験動物, 39, 43-48.

[5] Honjo, S., Cho, F., and Terao, K. (1984). Establishing the cynomolgus monkey as a laboratory animal. In Advances in Veterinary Science and Comparative Medicine, pp. 51-80. Vol. 28, Hendrickx (edit.), Academic Press, New York.

[6] Honjo, S. (1985). The Japanese Tsukuba Primate Center (TPC) : An outline, J. med Primatol, 14, 75-89.

[7] Kakoma, I., James, M. A., Jackson, W., Bennett, G., and Ristic, M. (1985). Hematologic values of normal bolivian squirrel monkeys (Saimiri scuureus) : a comparison between wild caught and laboratory bred male animals. Folia Primatol, 44, 102-107.

[8] Kessler, M. J. and Rawlins, R. G. (1983). Age- and pregnancy-related changes in serum total choles- 
terol and triglyceride in the Cayo Santiago rhesus macaques. Exp. Gerontol 18, 1-4.

[9] McMahan, M. R., Clarkson, T. B., Sackett, G. P., and Rudel, L. L. (1980). Changes in plasma lipides and lipoproteins in Macaca nemestrinaduring pregnancy and postpartum period. Proc. Soc. Exp. Biol Med, $164,199-206$.

[10］成田勇人・浜野政章・長 文昭 (1988). 超音波診断装 㯰によるリスザルの妊娠診断と胎仔の発育観察. 実験動 物, 37, 393-397.

[11］水谷敏郎 (1977). 妊婦に扩ける高脂血症に関寸る研究. 日産婦誌, 29, 986-994.

[12］奥野忠一.久米 均・芳賀敏朗・吉澤 正 (1971)，多 変量解析, pp. 259-322, 日科技連, 東京.

［13］須崎百合子・吉田高志（1988）。タマリン属サルの血液 および血清生化学値の妊娠にともなら変化. 実験動物, 37, 303-309.

［14］田中 豊・垂水共之・脇本和昌（1984），パソコン統計 解析ハンドブック】多变量解析編, pp. 138-159, 共立出 版, 東京.

[15] Yoshida, T. (1981). The changes of hematological and biochemical properties in cynomolgus monkeys (Macaca fascicularis) after imporrtation. Jpn. J. Med Sci Biol, 34, 239-242.

［16］吉田高志・鈴木絹江・長 文昭・本庄重男 (1986)。実 験用カニクイザルの成長にともなら血液学的および血清
生化学的測定値の変化. 実鉤動物, 35, 329-338.

［17］吉田高志・鈴木絹江・清水利行 - 長 文昭 - 本庄重男 (1986).メス・カニクイザル (Macaca fascicularis)の

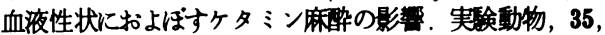
455-461.

［18］吉田高志・長 文昭・後藤信男 (1987). 実験用カ二ク イザルの成長にともな5血液学的および血清生化学的測 定値の変化，II. 多变量解析法の適用。実験動物，36, 245-251.

[19］吉田高志 · 大藤圭子 - 長 文昭 - 本庄重男 - 後藤信男 (1988). 1 歳棒末満メス・カニクイザルの血液学的およ び血清生化学的測定値への多变量解析法の適用. 実験動 物, 37, 39-44

[20］吉田高志 - 大藤圭子 - 長 文昭 - 本庄重男 - 後藤信男 (1988). 判別分析法による妊娠カニクイザルの血腋学的 および血清生化学的測定値の解析. 実検動物, 37，257262.

[21］吉田高志・大藤圭子・長 文昭・後藤信男(1990)．異な る飼育条件下におけるメス・カニクイザルの血液学的お よび血清生化学的測定値の比較. 実検動物, 39, 21-26.

[22］吉田高志・浜野政章・大久保文雄 - 大藤圭子・長，文 昭・後藤信男 (1991). 正準判別分析法によるリスザル (Saimiri sciurea)の血液・血清生化学値の周年変化の解 析. 成長, (印刷中)

［23］吉田高志・服部正策(1991)。リスザル (Saimiri sciurea) の下垂体一甲状腺系の周年変化. 成長, (投稿中) 